\title{
Collagen Type I Prevents Glyoxal-Induced Apoptosis in Osteoblastic Cells Cultured on Titanium Alloy
}

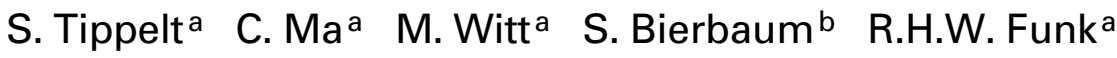 \\ Departments of a Anatomy and ${ }^{b}$ Biomaterials, Technical University, Dresden, Germany
}

\section{Key Words}

Collagen · Osteoblasts · Titanium alloys · Apoptosis . Glyoxal

\begin{abstract}
Advanced glycation end products (AGEs) irreversibly cross-link proteins with sugars and accumulate at a higher age and in diabetes, processes which can interfere with the integration of implants into the tissue. Glyoxal is a highly reactive glycating agent involved in the formation of AGEs and is known to induce apoptosis, as revealed by the upregulation of caspase- 3 and fractin (caspase-3 being a key enzyme activated during the late stage of apoptosis and fractin being a caspase-cleaved actin fragment). In this study, we investigated the influence of collagen type I coating on the cytotoxic effect
\end{abstract}

\section{Abbrevations used in this paper}

\section{AFM atomic force microscope}

AGEs Advanced glycation end products

BL uncoated (blank)

CML $\quad \varepsilon-\mathrm{N}$-(carboxymethyl)lysine

FC fibrillar collagen

FITC fluorescein isothiocyanate

GO glyoxal

PBS phosphate-buffered saline

SEM scanning electron microscope

Ti6Al4V titanium alloy of glyoxal on rat calvarial osteoblastic cells and on human osteosarcoma cells (Saos-2) grown on titanium alloy, Ti6Al4V. Activation of caspase-3 and fractin was measured by counting immunohistochemically stained cells and by flow cytometry with propidium iodide (detection of the apoptosis indicating a sub- $\mathrm{G}_{1}$ peak). Our results showed an increased number of apoptotic osteoblasts after incubation with glyoxal on Ti6AI4V discs. However, the number of apoptotic cells on collagencoated titanium was significantly smaller than on uncoated titanium after the same treatment. The present findings demonstrate that osteoblasts treated with glyoxal undergo apoptosis, whereas collagen type I coating of titanium alloys (used for implants) has an antiapoptotic function.

Copyright @ 2004 S. Karger AG, Base

\section{Introduction}

The ability of an implant to integrate into the bone is a prerequisite for clinical success [Cooper, 1998; Lohmann et al., 1999]. Implant surface coating, roughness and chemistry influence the adhesion, proliferation, and differentiation of osteoblastic cells on implants [Martin et al., 1995; Degasne et al., 1999].

Collagen type I is one of the major extracellular matrix proteins that can be found in fibrous tissue and bone. Precoating titanium alloy (Ti6Al4V) with collagen type I promotes adhesion and spreading of rat calvarial osteoblasts and leads to specific cell-implant interactions, which was

S. Tippelt, R.H.W. Funk

Department of Anatomy, University of Technology Dresden

Fetscherstrasse 74, DE-01307 Dresden (Germany)

Tel +49 3514586110 , Fax +493514586303

E-Mail Sonja.Tippelt@mailbox.tu-dresden.de, Richard.Funk@mailbox.tu-dresden.de
Fax + 41613061234 E-Mail karger@karger.ch www. karger.com

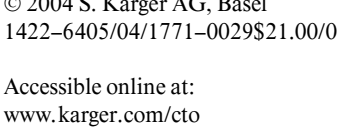


shown by our groups [Geissler et al., 2000; Röhlecke et al., 2001]. We have also shown that collagen contributes to cell spreading and a more rapid formation of focal adhesions [Röhlecke et al., 2001; Becker et al., 2002]. In general, the adhesion of cells to the extracellular matrix and cell-cell interactions have been observed to suppress apoptosis in many cell types, including osteoblasts [Boudteau et al., 1995; Krestow et al., 1999; Hunter et al., 2001].

According to these findings we hypothesized that collagen coating of titanium alloys is able to reduce apoptosis of osteoblasts due to changes in interactions between cells and extracellular matrix. To address this question, we exposed cultivated osteoblast-like cells with glyoxal, a known apoptosis-inducing agent which is involved in the formation of advanced glycation end products (AGEs) [Thornalley and Stern, 1984; Thornalley, 1999].

AGEs are heterogeneous stable end-stage substances formed by the nonenzymatic glycation of proteins, nucleotides and phospholipids. The accumulation of AGEs in vivo has been linked to normal aging and occurs at an accelerated rate in the development of diabetes complications and neurodegenerative diseases [Lyons et al., 1991; McCance et al., 1993]. Diabetes in both humans and rats is accompanied by impaired bone formation [Bouillon et al., 1995; Krakauer et al., 1995; Katayama et al., 1996; Takeshita et al., 1997].

Early glycation involves the reaction of glucose with $\mathrm{N}$-terminal and lysyl side chain amino groups to form Schiff's base and fructosamine adducts. Glucose $(50 \mathrm{mM})$ degrades slowly at $\mathrm{pH} 7.4$ and $37^{\circ} \mathrm{C}$ to form glyoxal (59.5 $\pm 3.7 \mu M)$, methylglyoxal $(2.77 \pm 1.22 \mu M)$ and 3-deoxyglucosone $(7.46 \pm 1.48 \mu \mathrm{M})$. The concentrations of these $\alpha$-oxoaldehydes increased rapidly in an in vitro assay over the initial 2-5 days [Thornalley et al., 1999]. In cells, transmembrane surface receptors for AGE include galectin-3, and the macrophage scavenger receptors $\mathrm{p} 60$ and $\mathrm{p} 90$ [Thornalley, 1998].

There is evidence that $\varepsilon-\mathrm{N}$-(carboxymethyl)lysine (CML) modifications of proteins are the predominant AGEs that accumulate in vivo [Berg et al., 1998; Kislinger et al., 1999; Wagner et al., 2001]. CML (which we use in this paper as immunostaining marker for 'aged' proteins) is a chemically defined AGE formed on proteins by glycation and lipid peroxidation as well as by auto-oxidation of lipids, amino acids and carbohydrates [Miyata and Kurrokawa, 1999]. In a previous study we could show that CML, bax and active caspase- 3 as well as apoptotic events increased after incubation with glyoxal [Reber et al., 2003].
In the present study, we examined the cytotoxic effect of glyoxal on osteoblasts in general, and then tested if collagen coating of titanium alloy reduced the cytotoxic effect of glyoxal.

Apoptotic cells were detected by flow cytometry (propidium iodide showing the apoptosis indicating a sub- $\mathrm{G}_{1}$ peak) and immunohistochemically using antibodies against caspase-3, a key enzyme during apoptosis, and against fractin, an actin fragment generated by caspase- 3 cleavage [Rossiter et al., 2000; Reber et al., 2002] and a valuable marker of apoptosis in various tissues [Pulera et al., 1998; Rossiter et al., 2000; Elibol et al., 2001].

Actin cleavage by caspase-3, in particular, results in the breakdown of the cytoskeleton membrane blebbing, and the release of DNase I, which enters the nucleus and induces DNA fragmentation [Kayalar et al., 1996]. The anti-fractin antibody was raised against the C-terminus $32-\mathrm{kD}$ actin fragment, which is formed by the caspase3-mediated cleavage at 244 aspartate residue [Yang et al., 1998]. It is specific for the $32-\mathrm{kD}$ fragment, but does not recognize the intact actin.

For clinical relevance we found it important to include both animal primary cultures (rat calvarial osteoblasts) and human cells (osteosarcoma cell line, Saos-2). Cell lines behave sometimes slightly differently compared to fresh primary cultures. On the other hand, it is important to also include human cells which allow a better comparison with the in vivo situation in patients.

\section{Materials and Methods}

\section{Preparation of Modified Surfaces}

As substrates for the cell experiments, the following surface states were used: Ti6Al4V coated with collagen type I (fibrillar collagen, FC) and Ti6 Al4V without coating [uncoated (blank), BL] prepared in collaboration with Dr. S. Bierbaum at the Department of Biomaterials at the TU Dresden.

Experiments were performed on glass coverslips with a diameter of $16 \mathrm{~mm}\left(2 \mathrm{~cm}^{2}\right)$ magnetron-sputtered with $50 \mathrm{~nm}$ Ti6Al4V alloy. Scanning electron microscope (SEM) and atomic force microscope (AFM) images of these metallic layers showed a cluster structure in the nanometer region. The sputtered Ti6Al4V substrates were cleaned with $1 \%$ Triton X-100, acetone and $96 \%$ ethanol, rinsed with distilled water, and air dried. The Ti6Al4V discs were coated with FC with an improved adsorption method [Rössler et al., 1999, 2000].

For collagen coatings, collagen fibrils were prepared by mixing in an equal amount of a fibrillogenesis buffer with $1 \mathrm{mg} / \mathrm{ml}$ solution of acid-soluble calf skin collagen type I (Fluka, Deisenhofen, Germany), which had been dissolved overnight in $10 \mathrm{~m} M$ acetic acid and then centrifuged $10,000 \mathrm{~g}$ for $30 \mathrm{~min}$ at $4^{\circ} \mathrm{C}$. Following overnight incubation at $37^{\circ} \mathrm{C}$, the resulting gel was homogenized, fibrils were collected by centrifugation at $5,000 \mathrm{~g}$ for $15 \mathrm{~min}$, washed with fibrillogenesis buffer diluted to a working concentration, and centrifuged 
Table 1. List of antibodies used for immunohistochemistry

\begin{tabular}{lllll}
\hline Antibody & Specificity & Species & Dilution & Source \\
\hline Caspase-3 & active caspase-3 & rabbit, polyclonal & $1: 20$ & $\begin{array}{l}\text { PharMingen } \\
\text { Heidelberg, Germany }\end{array}$ \\
\hline CML & CML & rabbit, polyclonal & $1: 1,000$ & $\begin{array}{l}\text { Dr. Schleicher } \\
\text { University of Tübingen, Germany }\end{array}$ \\
\hline Fractin & fractin & rabbit, polyclonal & $1: 1,000$ & $\begin{array}{l}\text { PharMingen } \\
\text { Heidelberg, Germany }\end{array}$ \\
& & & & \\
\hline
\end{tabular}

again. The pellet was resuspended in the same buffer to a concentration of $\sim 1 \mathrm{mg} / \mathrm{ml}$ collagen. The titanium-coated discs were incubated in suspension with collagen solution at $25^{\circ} \mathrm{C}$ for $15 \mathrm{~min}$, washed with distilled water, and air dried. For cell culture experiments, coated (FC) and uncoated (BL) discs were sterilized with $100 \%$ ethylene oxide at $42{ }^{\circ} \mathrm{C}$ for $12 \mathrm{~h}$. Morphological investigations were carried out with a digital SEM (DSM 982 Gemini; Carl Zeiss, Oberkochen, Germany) and an AFM (NanoScope IIIa; Digital Instruments, Santa Barbara, Calif., USA). There was no measurable detachment of collagen after exposure of the coated titanium alloy to the cell culture medium for several weeks [Lowenberg et al., 1988; Rössler et al., 1999; Geissler et al., 2000; Rössler et al., 2000]. Furthermore, members of our groups demonstrated on collagen type Icoated titanium alloys in rat tibiae that no abrasion of collagen type I from the implants occurred during 6-8 weeks of implantation time [Rammelt et al., 2002a, b].

\section{Cell Cultures}

The human osteoblast-like cell line, Saos- 2 cells, obtained from American Tissue Culture Collection (Manassas, Va., USA), and a p53-negative cell line, were grown at $37^{\circ} \mathrm{C}$ in $5 \% \mathrm{CO}_{2}$ in McCoy's $5 \mathrm{~A}$ medium supplemented with $15 \%$ fetal calf serum and $10 \mathrm{mg} / \mathrm{ml}$ gentamycin.

Primary osteoblasts were obtained from fetal rat calvarial samples by collagenase digestion. The bone samples were dissected to approximately $1-\mathrm{mm}^{3}$ fragments after removal of the periosteum. They were washed first with Tyrode's solution and then with Ham's F12 medium. They were then digested in $4 \mathrm{ml}$ of collagenase-trypsin solution [137 mg of collagenase type I (Biochrom, Berlin, Germany) and $50 \mathrm{mg}$ of trypsin type III (Sigma, Deisenhofen, Germany) in $10 \mathrm{ml}$ of deionized $\mathrm{H}_{2} \mathrm{O}$ containing $8 \mathrm{~g}$ of $\mathrm{NaCl}, 0.2 \mathrm{~g}$ of $\mathrm{KCl}$ and $0.05 \mathrm{~g}$ of $\mathrm{NaH}_{2} \mathrm{PO}_{4} \cdot \mathrm{H}_{2} \mathrm{O}$ per $100 \mathrm{ml}$ of deionized $\mathrm{H}_{2} \mathrm{O}$ ] at room temperature. Cells from the first $45-\mathrm{min}$ digestion were discarded. The second and third 30-min digests (in $4 \mathrm{ml}$ of fresh collagenase-trypsin solution) were centrifuged for $2 \mathrm{~min}$ at $600 \mathrm{~g}$. The cell pellets were resuspended in $4 \mathrm{ml}$ Ham's F12 medium containing 20\% fetal calf serum. After $10 \mathrm{~min}$ of centrifugation at $500 \mathrm{~g}$, the cells were plated in full medium, i.e. $12 \mathrm{ml}$ of Ham's F12 medium containing $12 \%$ fetal calf serum, $2.3 \mathrm{mM} \mathrm{Mg}{ }^{2+}, 100 \mathrm{IU} / \mathrm{ml}$ penicillin and $100 \mu \mathrm{g} / \mathrm{ml}$ streptomycin sulfate. The medium was changed every 3 days. The osteoblast phenotype was characterized by determining alkaline phosphatase activity, collagen type I synthesis and formation of calcium phosphate deposits. The cells for each experiments were used for 5 th and 6 th passages. The cultures were maintained at $37^{\circ} \mathrm{C}$ in humidified air and $5 \% \mathrm{CO}_{2}$. Cell viability was assessed by trypan blue dye exclusion.

\section{Application of Cells to Implants and Exposure to Glyoxal}

The titanium-coated discs were placed into 12-well Falcon culture plates (Becton Dickinson, Heidelberg, Germany). Primary osteoblasts and Saos-2 cells were detached using $0.05 \%$ trypsin- $0.02 \%$ EDTA in phosphate-buffered saline (PBS) and plated on the discs to a single-cell density of 10,000 cells $/ \mathrm{cm}^{2}$. Cells were allowed to settle for $2 \mathrm{~h}$ in the incubator at $37^{\circ} \mathrm{C}$ in PBS, which was then replaced with $2 \mathrm{ml}$ complete medium and nonadherent cells were gently removed. After $24 \mathrm{~h}$ in culture, primary osteoblasts were treated for 24 or $72 \mathrm{~h}$ with $0 \mu M$ (control), 100, 200, 400 and $600 \mu M$ glyoxal (40\% aqueous solution; Sigma-Aldrich) while Saos-2 cells were treated for the same time with 0 (control), 50,100, 200 and $300 \mu M$ glyoxal. For the sub- $\mathrm{G}_{1}$ test (see Flow Cytometry below), the Saos-2 cells were treated for 24 or $72 \mathrm{~h}$ with 200,300 and $400 \mu M$ glyoxal. Cell viability prior to incubation with glyoxal was assessed by trypan blue dye exclusion.

\section{Immunocytochemistry and Quantitative Microscopy}

For immunocytochemistry, the medium was removed and cells were washed 3 times with PBS. Cells were then fixed with $4 \%$ buffered paraformaldehyde for $5 \mathrm{~min}$ at room temperature. After washing with PBS, cells were permeabilized with $0.5 \%$ Triton X-100 in PBS for $6 \mathrm{~min}$ and then incubated with $1 \%$ bovine serum albumin for $10 \mathrm{~min}$. Cells were incubated overnight at $4{ }^{\circ} \mathrm{C}$ with polyclonal, antisera against caspase-3 (active caspase-3, rabbit, polyclonal; 1:20; PharMingen, Heidelberg, Germany), fractin (rabbit, polyclonal, 1:1,000; Dr. Schleicher, University of Tübingen) or CML (rabbit, polyclonal, 1:1,000; PharMingen) (table 1). After washing, the cells were exposed to a fluorescein isothiocyanate (FITC)-conjugated goat anti-rabbit secondary antibody (1:100; Dianova, Hamburg, Germany) for $1 \mathrm{~h}$ at room temperature. After rinsing 3 times with PBS, bisbenzimid (Hoechst; 1:1,000) was added for $15 \mathrm{~min}$. Cellular fluorescence was evaluated with a conventional fluorescence microscope (Leica, Bensheim, Germany). The FITC wavelengths for excitation average at $490 \mathrm{~nm}$ and emission at $525 \mathrm{~nm}$, bisbenzimid wavelengths for excitation at $365 \mathrm{~nm}$ and emission at $480 \mathrm{~nm}$. Pictures were captured with a Nikon Coolpix 995.

After staining with bisbenzimid, apoptotic cells exhibited in blue condensed nuclei and fragmented chromatin. Quantification of apoptotic cells in each culture condition was performed by counting the number of cells with fragmented chromatin within six random fields of sight $\left(0.5985 \mathrm{~mm}^{2}\right)$. Experiments were independently repeated 9 times. Data are presented as mean \pm SD. Differences between Ti6Al4V collagen type I (FC) and Ti6Al4V uncoated (BL) were evaluated with the paired Student $t$ test. The Student $t$ test is a parametric test for the comparison of the average values of two inde- 
Fig. 1. Percentage of apoptotic cells (with fragmented chromatin, staining with bisbenzimid) of calvarial (A, B) and Saos-2 (C, D) cells after treatment for $24 \mathrm{~h}(\mathbf{A}, \mathbf{C})$ and $72 \mathrm{~h}$ (B, D) with different glyoxal (GO) concentrations. Cells were cultured on BL and FCcoated titanium alloy. The histogram shows the influence of FC on the antiapoptotic behavior of calvarial cells and Saos-2 cells after incubation of cells with various GO concentrations. Representative data from nine experiments are shown. $* \mathrm{p}<0.05$; $* * \mathrm{p}<0.01$ FC vs. BL.

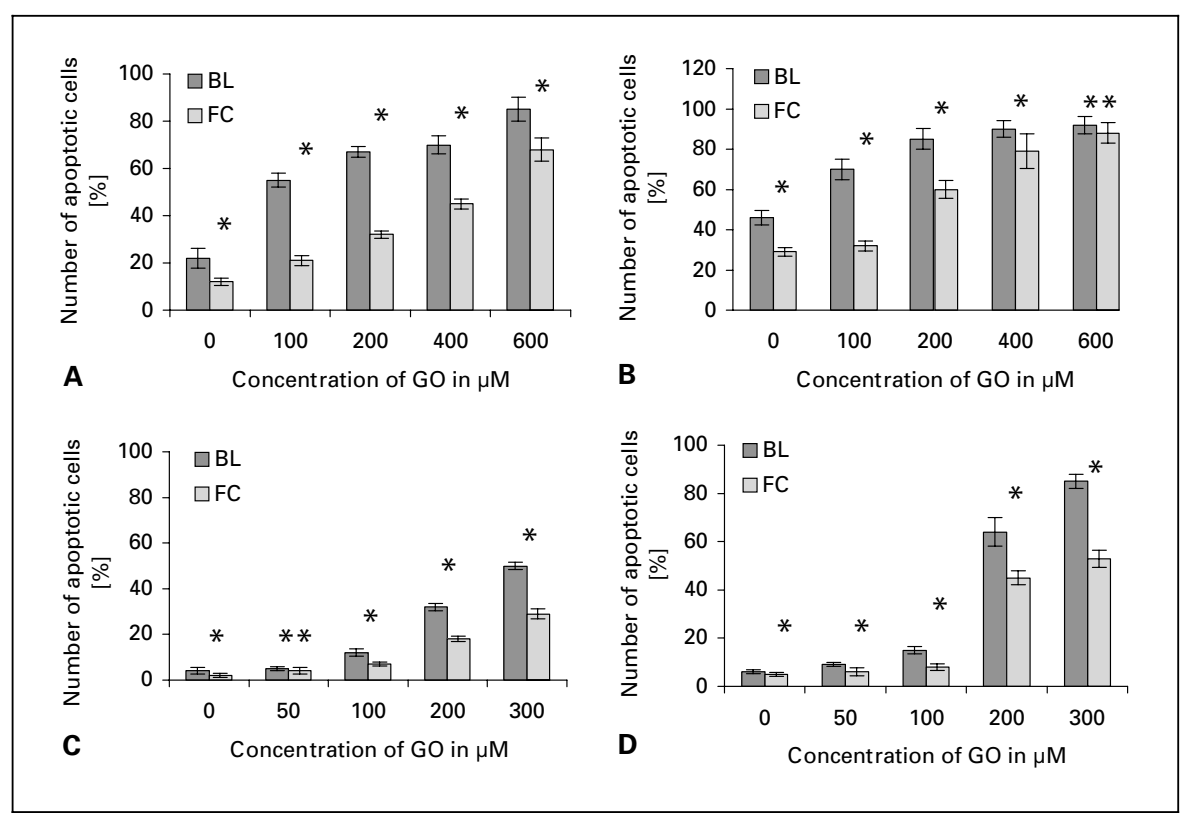

pendent samples out of the normally distributed universe test statistic t. Calculations were performed using the statistical package SPSS 11.0 (SPSS, Professional Statistics, Chicago, Ill., USA) and significance was accepted at $* p<0.05 ; * * p<0.01$ FC vs. BL.

\section{Flow Cytometry}

Apoptosis of cells plated on Ti6Al4V-coated discs with (FC) or without (BL) collagen type I was assessed by flow cytometry (sub- $\mathrm{G}_{1}$ ) as described [Nicoletti et al., 1991] after treatment with $300 \mu M$ of glyoxal. Control cells were grown on the same plates, but were not exposed to glyoxal. Briefly, cells were fixed by adding $70 \%$ ethanol. Fragmented DNA was extracted with a buffer containing $0.192 M$ $\mathrm{Na}_{2} \mathrm{HPO}_{4}$ and $4 \mathrm{~m} M$ citric acid, $\mathrm{pH}$ 7.8. Staining was performed with $20 \mu \mathrm{g} / \mathrm{ml}$ propidium iodide and $200 \mu \mathrm{g} / \mathrm{ml} \mathrm{RNase} \mathrm{A} \mathrm{(Becton}$ Dickinson) in PBS, pH 7.4 for 30 min at room temperature. Cells were analyzed using a FACSCalibur (Becton Dickinson) [Darzynkiewicz et al., 1992]. Apoptotic cells were revealed by a hypodiploid DNA peak with a weaker fluorescence than the normal $G_{1}$ peak [Gong et al., 1994].

\section{Results}

Glyoxal-Induced Apoptosis in Rat Calvarial Cells and Saos-2 Osteoblastic Cells

Figure 1 shows the percentage of calvarial (fig. 1A, B) and Saos-2 (fig. 1C, D) apoptotic cells after treatment with different glyoxal concentrations for $24 \mathrm{~h}$ (fig. 1A, C) and $72 \mathrm{~h}$ (fig. 1B, D) by counting the bisbenzimid-stained fragmented and condensed nuclei.

In calvarial cells, glyoxal for $24 \mathrm{~h}$ induced apoptosis in a dose-dependent manner: 100, 200, 400 and $600 \mu M$ glyoxal induced apoptosis in 55, 67, 70 and $85 \%$ of the cells, respectively (fig. 1A). After $72 \mathrm{~h}$ incubation with glyoxal at the indicated concentrations, the apoptotic cell rate was further increased to 70, 85, 90 and $92 \%$ (fig. 1B).

A similar dose- and time-response to glyoxal was observed in Saos- 2 cells (fig. 1C, D). Treatment over a period of $24 \mathrm{~h}$ with $50,100,200$ and $300 \mu M$ glyoxal induced 5, 12, 32 and 50\% apoptosis of Saos- 2 cells, respectively (fig. 1C). After $72 \mathrm{~h}$ glyoxal treatment, the corresponding apoptosis rates increased to 9, 15, 64 and $85 \%$ (fig. 1D). Higher concentrations or longer incubation with glyoxal induced $100 \%$ cell death. In general, Saos-2 cells responded to lower glyoxal concentrations than calvarial cells.

Furthermore, fewer calvarial cells and even fewer Saos- 2 cells underwent apoptosis on collagen-coated titanium discs (FC) than on uncoated titanium discs (BL) (compare fig. 1A and B with fig. $1 \mathrm{C}$ and D). Thus, the collagen coating had a protective effect, with a decreased apoptotic rate in Saos- 2 cells (10-30\% less) compared to uncoated surfaces. In addition, these results revealed that even a small concentration of glyoxal is sufficient to induce apoptosis of human cells.

The sub- $\mathrm{G}_{1}$ tests by flow cytometry corroborated our microscopical observations. Higher concentrations and longer incubation with glyoxal resulted in increased apoptotic rates (fig. 2). Moreover, the number of apoptotic cells on collagen-coated titanium was much smaller than on uncoated titanium. For instance, after treatment with 
$300 \mu M$ glyoxal for $24 \mathrm{~h}$, propidium iodide fluorescence was much higher in Saos-2 cells grown on uncoated than on collagen-coated discs. Data are shown in figure 2.

\section{Glyoxal-Induced Apoptosis: Upregulation of \\ Caspase-3, Fractin and CML}

Double immunofluorescence (bisbenzimid and caspase-3 or fractin) demonstrated that treatment with glyoxal caused the activation of caspase-3 (fig. 3 ) and fractin (fig. 4) in calvarial and Saos-2 cells, as expected in apoptotic cells.

In the absence of glyoxal, cell cultures grown on collagen-coated or uncoated titanium discs included fewer apoptotic cells, as revealed by staining for activated caspase-3 and fractin (data not shown). Double immunofluoresence showed that fractin-positive cells were identical to those undergoing nuclear fragmentation (fig. 4).

Fig. 2. Apoptotic Saos-2 cells after treatment for $24 \mathrm{~h}$ with $300 \mu M$ glyoxal $(\mathrm{GO})$ detected by sub- $\mathrm{G}_{1}$ test. --- = Untreated control. BL $(-)$ and FC (......) represent treated cells either $300 \mu M$ glyoxal. The sub- $\mathrm{G}_{1}$ test shows the influence of FC on the antiapoptotic behavior of Saos- 2 cells after incubation of cells with $300 \mu M$ GO.

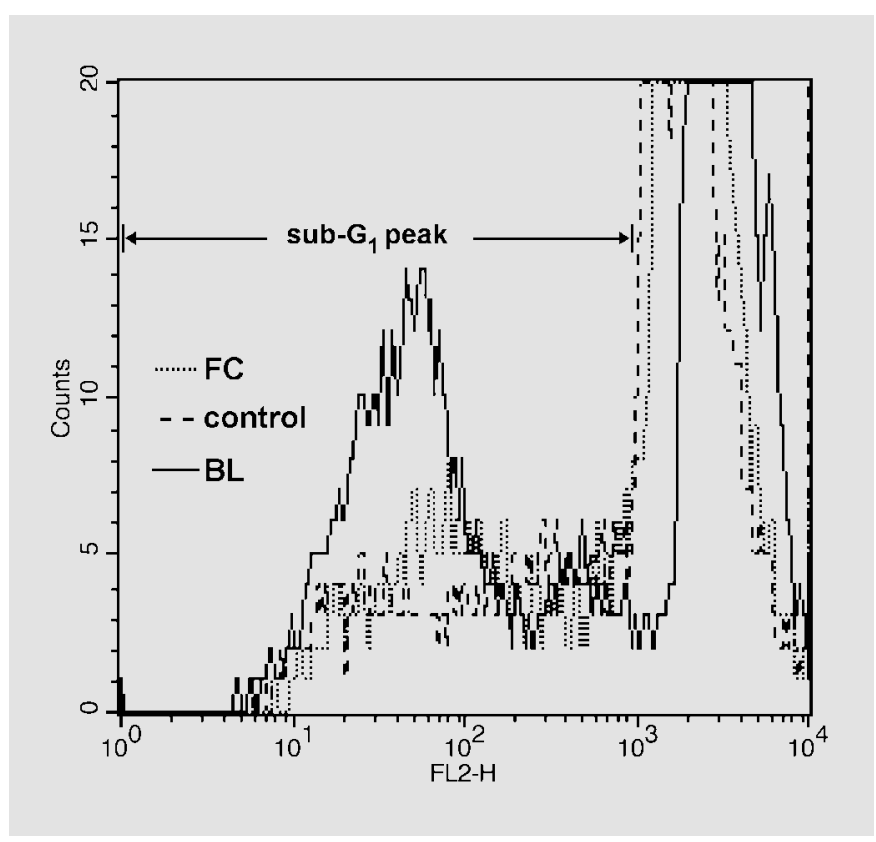

The experiment revealed the lowest apoptotic rate in controls (the controls grew only on culture plates without glyoxal), followed by those on FC-coated titanium alloy. The highest apoptotic cell rate we determined was on BL titanium alloy.
Fig. 3. Apoptotic calvarial cells after $24 \mathrm{~h}$ treatment with $200 \mu M$ glyoxal (GO) cultured on BL $(\mathbf{A}, \mathbf{B})$ and $\mathrm{FC}(\mathbf{C}, \mathbf{D})$ titanium alloy detected by reactions with bisbenzimid $(\mathbf{A}, \mathbf{C})$ combined with anti-caspase-3 immunocytochemistry (B, D). Identical cells are shown in $\mathbf{A}+\mathbf{B}$ and $\mathbf{C}+\mathbf{D}$. The arrows marked identical cells. The immunocytochemistry demonstrates that only apoptotic cells $($ A, C) produced anti-caspase-3 (B, D). Double immunofluorescence showed that more apoptotic cells were present on $\mathrm{BL}(\mathbf{A}, \mathbf{B})$ than on $\mathrm{FC}(\mathbf{C}, \mathbf{D})$. Anti-caspase-3 expression was quantitatively decreased on FC correlating with a lower number of apoptotic cells. Scale bar for A-D is $10 \mu \mathrm{m}$.
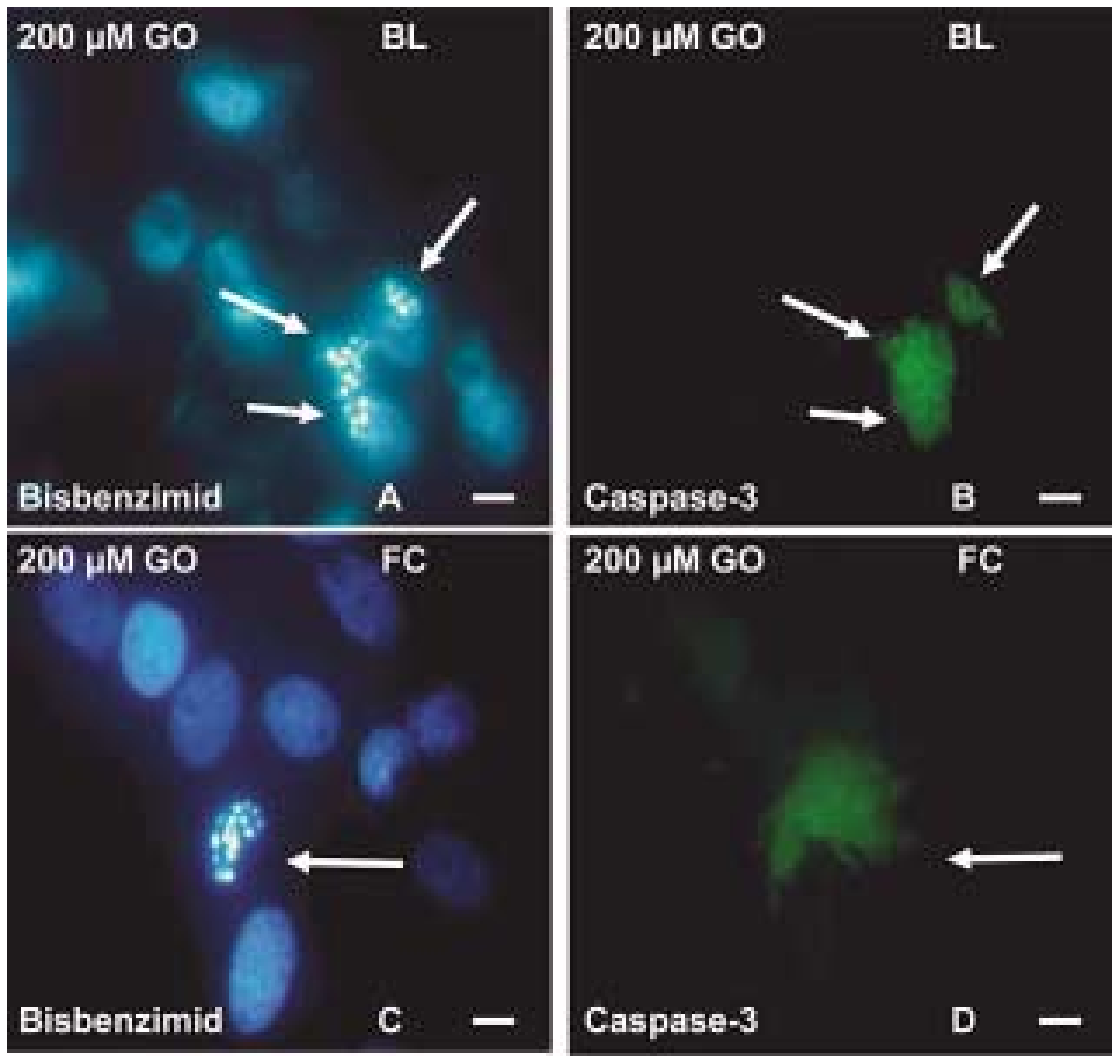
Fig. 4. Apoptotic calvarial cells after $24 \mathrm{~h}$ treatment with $200 \mu M$ glyoxal (GO) cultured on BL $(\mathbf{A}, \mathbf{B})$ and FC (C, D) titanium alloy detected by reactions with bisbenzimid $(\mathbf{A}, \mathbf{C})$ combined with antifractin immunocytochemistry (B, D). Identical cells are shown in $\mathbf{A}+\mathbf{B}$ and $\mathbf{C}+\mathbf{D}$. The arrows marked identical cells. The immunocytochemistry demonstrates that only apoptotic cells $(\mathbf{A}, \mathbf{C})$ produced antifractin (B, D). Double immunofluorescence showed that more apoptotic cells were present on BL $(\mathbf{A}, \mathbf{B})$ than on FC $(\mathbf{C}, \mathbf{D})$, where antifractin expression was quantitatively decreased on FC correlating with a lower number of apoptotic cells. Scale bar for A-D is $10 \mu \mathrm{m}$.

Fig. 5. Apoptotic calvarial cells after $24 \mathrm{~h}$ treatment with $200 \mu M$ glyoxal (GO) cultured on BL (A, B) and FC (C, D) titanium alloy detected by reactions with bisbenzimid $(\mathbf{A}, \mathbf{C})$ combined with anti-CML immunocytochemistry (B, D). Identical cells are shown in $\mathbf{A}+\mathbf{B}$ and $\mathbf{C}+\mathbf{D}$. The arrows marked identical cells. The immunocytochemistry demonstrates that only apoptotic cells $(\mathbf{A}, \mathbf{C})$ produced anti-CML (B, D) expressions. Double immunofluorescence showed that more apoptotic cells were present on $\mathrm{BL}(\mathbf{A}, \mathbf{B})$ than on $\mathrm{FC}(\mathbf{C}, \mathbf{D})$, where anti-CML was quantitatively decreased on FC correlating with a lower number of apoptotic cells. Scale bar for A-D is $10 \mu \mathrm{m}$.
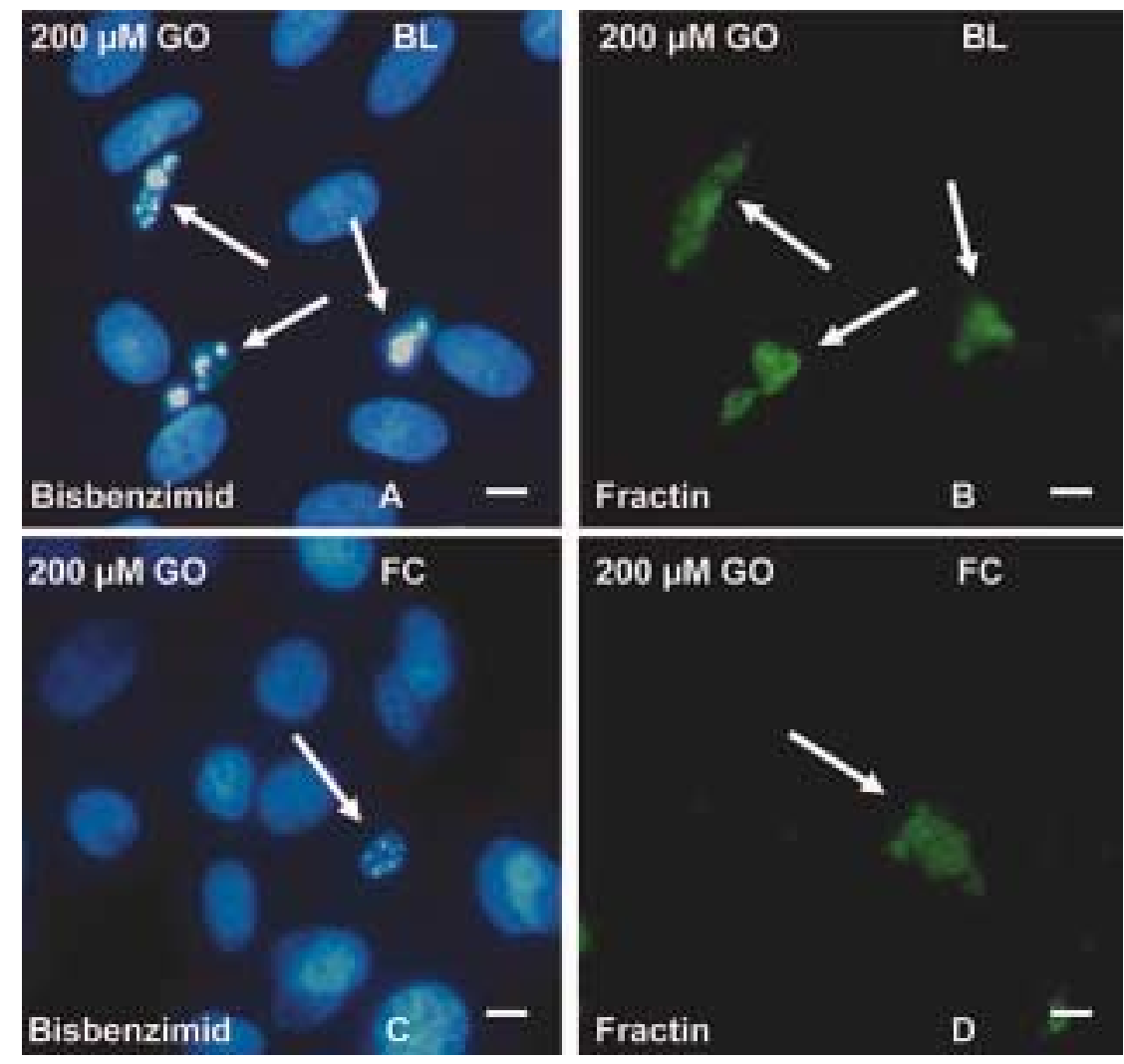

$200 \mu M$ GO
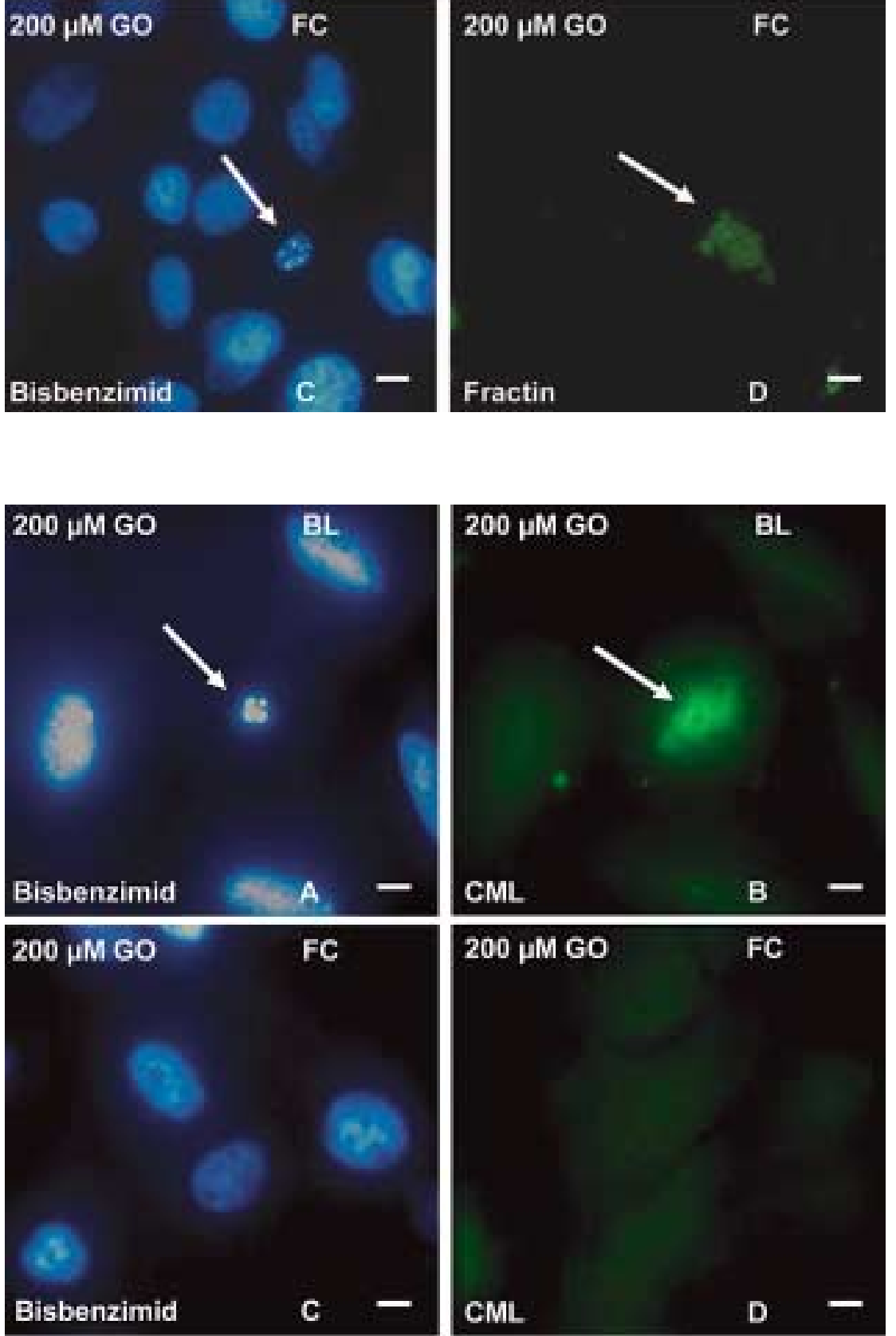
The effect of glyoxal on the accumulation of the AGE product CML in apoptotic cells was also assessed by double immunocytochemistry (fig. 5). These double immunofluorescence assays showed that CML-positive cells were identical to those undergoing nuclear fragmentation. Again, the number of these cells (Saos-2) was higher on uncoated titanium discs than on collagen type I-coated discs.

\section{Discussion}

An implant material attains and maintains contacts with interfacial tissue through its surface. Since reactions in vivo are governed by molecular mediators, it is conceivable that these mediators play a role in the process leading to implant integration or rejection. When a substrate or an implant is inserted into the living tissue, it is exposed to cells and a large variety of ionic and molecular species that ultimately affect the course of the events at the interface between the tissue and the implant.

A very early event in the implantation process is the adsorption of proteins onto the substrate. Collagen type I is the predominant matrix protein in the bone tissue and plays an important role in bone cell-matrix interactions. The initial adhesion and differentiation of osteoblasts are improved by coating titanium alloy with collagen type I [Geissler et al., 2000; Röhlecke et al., 2001; Becker et al., 2002]. The adhesion of cells to the extracellular matrix and intercellular contact have been observed to suppress apoptosis in many cell types. For example, glyoxal treatment in epithelial lung L132 cells induced apoptosis as a consequence of the loss of cell contacts and simultaneous downregulation of cell adhesion molecules, such as $\beta_{1}$ integrin, CD44 and ICAM-1 [Röhlecke et al., 2000]. The collagen framework is also important for the survival of cells shown in human cartilage [Kim et al., 2001]. Correspondingly, collagenase treatment leads to an increased apoptosis.
Both $\mathrm{p} 53$ and $\mathrm{pRb}$, the latter being a product of the retinoblastoma gene, are implicated in certain pathways of apoptosis. Saos- 2 cells are defective in the expression of both $\mathrm{p} 53$ and $\mathrm{pRb}$. Nevertheless, our findings indicate that glyoxal can induce apoptosis of these p53/pRb-negative cells. In addition, we found that caspase activation is involved in glyoxal-mediated apoptosis, as caspase-3 activity and fractin expression were increased in glyoxaltreated, bisbenzimid-positive cells.

In diabetic rats and humans, marked abnormalities in bone metabolism have been described, characterized by a decreased number of osteoblasts, decreased bone formation and slow turnover, all of which contribute to osteoporosis [Vaeghe et al., 1990; Bouillon et al., 1995]. Treatment with glyoxal promotes the formation of CML residue on proteins, which can mimic diabetes-induced damage [Berg et al., 1998; Rico et al., 1998]. Our present results prove that glyoxal, indeed, induces the formation of the AGE product CML and CML accumulation is concomitant with a markedly increased apoptosis.

The present findings show (as important findings for implant modification) that the coating of titanium alloy with collagen type I exerts a protecting, antiapoptotic effect on osteoblasts. The mechanisms behind this effect are still unclear, but one could propose that collagen exerts a scavenging action on radicals generated by AGEs [Loske et al., 1998] or that it directly cross-links with AGEs, as previously suggested [Mentink et al., 2002]. Thus, implants coated with collagen could have beneficial effects especially in patients with longer implant duration, advanced age and diabetes.

\section{Acknowledgments}

We are grateful to Mrs. K. Pehlke and Mrs. B. Rost who provided help with the cell cultures, and to Mr. T. Schwalm who helped with the editing of the figures. This work was supported by a grant from the Deutsche Forschungsgemeinschaft (FOR 308/2-1).

\section{References}

Becker, D., U. Geissler, U. Hempel, S. Bierbaum, D. Scharnweber, H. Worch, K.W. Wenzel (2002) Proliferation and differentiation of rat calvarial osteoblasts on type I collagen-coated titanium alloy. J Biomed Mater Res 59: 516527.
Berg, T.J., J.T. Clausen, P.A. Torjesen, K. DahlJordensen, H.J. Bangstad, K.F. Hanssen (1998) The advanced glycation end product Nepsilon(carboxymethyle)lysine is increased in serum from children and adolescents with type 1 diabetes. Diabetes Care 21: 1997-2002.

Boudteau, N., C.J. Sympson, Z. Werb, M.J. Bissel (1995) Suppression of ICE and apoptosis in mammary epithelial cells by extracellular matrix. Science 267: 891-893.
Bouillon, R., M. Bex, E. Van Herck, J. Laureys, L. Doom, E. Lesaffre, E. Ravussin (1995) Influence of age, sex, and insulin on osteoblast function: Osteoblast dysfunction in diabetes mellitus. J Clin Endocrinol Metab 80: 11941202.

Apoptosis on Collagen-Coated Titanium 
Cooper, L.F. (1998) Biologic determinants of bone formation for osseointegration: Clues for future clinical improvements. J Prosthet Dent 80 . 439-449.

Darzynkiewicz, Z., S. Bruno, G. Del Bino, W. Gorczyca, M.A. Hotz, P. Lassota, F. Traganos (1992) Features of apoptotic cells measured by flow cytometry. Cytometry 13: 795-808.

Degasne, I., M.F. Basle, V. Demais, G. Hure, M. Lesourd, B. Grolleau, L. Mercier, D. Chappard (1999) Effects of roughness, fibronectin and vitronectin on attachment, spreading, and proliferation of human osteoblast-like cells (Saos2) on titanium surfaces. Calcif Tissue Int 64 . 499-507.

Elibol, B., F. Söylemezoglu, I. Ünal, M. Fujil, T. Dalkara (2001) Nitric oxide is involved in ischemia-induced apoptosis in brain: A study in neuronal nitric oxide synthase-null mice. Neuroscience 105: 79-86.

Geissler, U., U. Hempel, C. Wolf, D. Scharnweber, H. Worch, K.W. Wenzel (2000) Collagen type I-coating of Ti6Al4V promotes adhesion of osteoblasts. J Biomed Mater Res 51: 752-760.

Gong, J., F. Traganos, Z. Darzynkiewicz (1994) Analysis of apoptotic cells by flow and laser scanning cytometry. Anal Biochem 218: 314.

Hunter, I., D. McGregor, S.P. Robins (2001) Caspase-dependent cleavage of cadherins and catenins during osteoblast apoptosis. J Bone Miner Res 16: 466-477.

Katayama, Y., S. Celic, N. Nagata, T.J. Martin, D.M. Findlay (1996) Role of nonenzymatic glycosylation of type 1 collagen in diabetic osteopenia. J Bone Miner Res 11: 931-937.

Kayalar, C., T. Ord, M.P. Teasta, L.T. Zhong, D.E. Bresen (1996) Cleavage of actin by interleukin $1 \beta$-converting enzyme to reverse DNase I inhibition. Proc Natl Acad Sci USA 93: 2234 2238.

Kim, H.A., D.I. Suh, Y.W. Song (2001) Relationship between chondrocyte apoptosis and matrix depletion in human articular cartilage. $\mathrm{J}$ Rheumatol 28: 2038-2045.

Kislinger, T., C. Fu, B. Huber, W. Qu, A. Taguchi, S. Du Yan, M. Hofmann, S.F. Yan, M. Pischetsrieder, D. Stern, A.M. Schmidt (1999) N(epsilon)-(carboxymethyl)lysine adducts of proteins are ligands of receptor for advanced glycation end products that activate cell signaling pathways and modulate gene expression. J Biol Chem 274: 31740-31749.

Krakauer, J.C., M.J. McKenna, N.F. Buderer, D.S Rao, F.W. Whitehouse, A.M. Parfitt (1995) Bone loss and bone turnover in diabetes. Diabetes 44: 775-782.

Krestow, J.K., J. Rak, J. Filmus, R.S. Kerbel (1999) Functional dissociation of anoikis-like cell death and activity of stress activated protein kinase. Biochem Biophys Res Commun 260 . 48-53.

Lohmann, C.H., R. Sagun Jr, V.L. Sylvia, D.L. Cochran, D. Dean, B.D. Boyan, Z. Schwartz (1999) Surface roughness modulates the response of MG63 osteoblast-like cells to 1,25$(\mathrm{OH})_{2} \mathrm{D}_{3}$ through regulation of phospholipase $\mathrm{A}_{2}$ activity and activation of protein kinase A. $\mathrm{J}$ Biomed Mater Res 80: 439-449.
Loske, C., A. Neumann, A.M. Cunningham, K. Nichol, R. Schinzel, P. Riederer, G. Munch (1998) Cytotoxicity of advanced glycation endproducts is mediated by oxidative stress. $\mathrm{J}$ Neural Transm 105: 1005-1015.

Lowenberg, B.F., R.M. Pillar, J.E. Aubin, J. Sodek, A.H. Melcher (1988) Cell attachment of human gingival fibroblasts in vitro to porous-surfaced titanium alloy discs coated with collagen and platelet-derived growth factor. Biomaterials 9: 302-309.

Lyons, T.J., G. Silvestri, J.A. Dunn, D.G. Dyer, J.W. Baynes (1991) Role of glycation in modification of lens crystallins in diabetic and nondiabetic senile cataracts. Diabetes 40: 10101015.

Martin, J.Y., Z. Schwartz, T.W. Hummert, D.M. Schraub, J. Simpson Lankford Jr, D.D. Dean, D.L. Cochran, B.D. Boyan (1995) Effect of titanium surface roughness on proliferation, differentiation and protein synthesis of human osteoblast-like cells (MG63). J Biomed Mater Res 64: 499-507.

McCance, D.R., D.G. Dyer, J.A. Dunn, K.E. Bailie, S.R. Thorpe, J.W. Baynes, T.J. Lyons (1993) Maillard reaction products and their relation to complications in insulin-dependent diabetes mellitus. J Clin Invest 91: 12431252.

Mentink, C.J., M. Hendriks, A.A. Levels, B.H. Wolffenbuttel (2002) Glucose-mediated crosslinking of collagen in rat tendon and skin. Clin Chim Acta 321: 69-76.

Miyata, T., K. Kurrokawa (1999) Carboxynyl stress: Increases carbonyl modification of proteins by autoxidation products of carbohydrates and lipids in uremia. Int $\mathbf{J}$ Artif Organs 22: 195-198.

Nicoletti, I., G. Migliorati, M.C. Pagliacci, F. Grignani, C. Riccardi (1991) A rapid and simple method for measuring thymocyte apoptosis by propidium iodide staining and flow cytometry. J Immunol Methods 139:271-279.

Pulera, M.R., L.M. Adams, H. Liu, D.G. Santos, C.G. Wasterlain (1998) Apoptosis in neonatal rat model of cerebral hypoxia-ischemia. Stroke 29: 2622-2630.

Rammelt, S., E. Schulze, U. Hanisch, E. Wolf, D. Scharnweber, A. Biewener, H. Worch, $\mathrm{H}$. Zwipp (2002a) Die Gewebereaktion auf Kollagen-Typ-I-beschichtete Titanstifte in der Rattentibia - Immunhistochemische Darstellung am Schliffpräparat (Technovit 9100 N) (abstract). Biomaterialien 3: 182

Rammelt, S., E. Schulze, E. Wolf, E.D. Scharnweber, M. Holch, H. Worch, H. Zwipp (2002b) Immunhistochemical characterisation of the interface on collagen-coated titanium pins in the undecalcified rat tibia. Eur J Trauma 28: 125-126.

Reber, F., R. Geffarth, M. Kasper, A. Reichenbach, E.D. Schleicher, A. Siegner, R.H.W. Funk (2003) Graded sensitiveness of the various retinal neuron population on the glyoxal-mediated formation of advanced glycation end products and ways of protection. Clin Exp Ophthalmol 241: 213-225.
Reber, F., M. Kasper, A. Siegner, E. Kniep, G. Seigel, R.H.W. Funk (2002) Alteration of the intracellular $\mathrm{pH}$ and apoptosis induction in a retinal cell line by the AGE-inducing agent glyoxal. Clin Exp Ophthalmol 240: 1022 1032.

Rico, H., E.R. Hernandez, J.A. Cabranes, F. Gomez-Castresana (1998) Suggestion of a deficient osteoblastic function in diabetes mellitus: The possible cause of osteopenia in diabetics. Calcif Tissue Int 45: 71-73.

Röhlecke, C., A.K. Kuhnt, H. Fehrenbach, C. Werner, R.H.W. Funk, M. Kasper (2000) Resistance of L132 lung cell clusters to glyoxalinduced apoptosis. Histochem Cell Biol 114. 283-292.

Röhlecke, C., M. Witt, M. Kasper, E. Schulze, C. Wolf, A. Hofer, R.H.W. Funk (2001) Synergistic effect of titanium alloy and collagen type I on cell adhesion, proliferation and differentiation of osteoblast-like cells. Cells Tissues Organs 168: 178-187.

Rossiter, J.P., L.L. Anderson, F. Yang, G.M. Cole (2000) Caspase-cleaved actin (fractin) immunolabelling of Hirano bodies. Neuropathol Appl Neurobiol 26: 342-346.

Rössler, S., D. Scharnweber, C. Wolf, H. Worch (1999) Immobilization of type I collagen on the alloy Ti6Al4V. J Mater Sci Lett 18: 577-579.

Rössler, S., D. Scharnweber, C. Wolf, H. Worch (2000) Investigation of the adsorption of tropocollagen type I on titanium and Ti6Al4V. J Adhesion Sci Technol 3: 453-465.

Takeshita, F., S. Iyama, Y. Ayukawa, M.A. Kido, K. Murai, T. Suetsugu (1997) The effects of diabetes on the interface between hydroxyaptite implants and bone in rat tibia. J Periodontol 68: 180-185.

Thornalley, P.J. (1998) Cell activation by glycated proteins. AGE receptors, receptor recognition factors and functional classification of AGEs. Cell Mol Biol (Noisy-le-grand) 44: 1013-1023.

Thornalley, P.J. (1999) Clinical significance of glycation. Clin Lab 56: 263-273.

Thornalley, P.J., A. Langborg, H.S. Minhas (1999) Formation of glyoxal, methylglyoxal and 3deoxyglucosone in the glycation of proteins by glucose. Biochem J 344: 109-116.

Thornalley, P.J., A. Stern (1984) The production of free radicals during the autoxidation of monosaccharides by buffer ions. Carbohydr Res 134 . 191-204.

Vaeghe, J., E. Van Herck, W.J. Visser (1990) Bone and mineral metabolism in BB rats with longterm diabetes. Decreased bone turnover and osteoporosis. Diabetes 39: 477-482.

Wagner, Z., I. Wittmann, I. Mazak, R. Schinzel, A. Hiedland, R. Kientsch-Engel, J. Nagy (2001) $\mathrm{N}$ (epsilon)-(carboxymethyl)lysine levels in patients with type 2 diabetes: Role of renal function. Am J Kidney Dis 38: 785-791.

Yang, F., X. Xun, W. Beech, B. Teter, S. Wu, G.M. Cole (1998) Antibody to caspase-cleaved actin detects apoptosis in differentiated neuroblastoma and plaque-associated neurons and microglia in Alzheimer's disease. Am J Pathol 152: 379-389. 